\title{
Phenotypic variation and traits interrelationships in bread wheat (Triti- cum aestivum L.) genotypes in Northern Ethiopia
}

\author{
Ahmed GETACHEW ${ }^{1}$, Fisseha WOREDE ${ }^{2,3}$ and Sentayehu ALAMEREW ${ }^{4}$
}

Received October 02, 2019; accepted August 10, 2021.

Delo je prispelo 2. oktobra 2019, sprejeto 10. avgusta 2021

\begin{abstract}
Phenotypic variation and traits interrelationships in bread wheat (Triticum aestivum L.) genotypes in Northern Ethiopia

Abstract: Information on phenotypic variation helps to breed better varieties. Forty-nine bread wheat genotypes were evaluated in simple lattice design at Jamma and Geregera to determine the extent of variation and association among 11 traits. Analysis of variance showed significant differences $(p<0.01)$ among the genotypes for all traits, indicating the presence of adequate variability. Maximum values of genotypic coefficients of variation were recorded for spike length $(8.66 \%)$, number of productive tillers $(8.4 \%)$, number of grains per spike $(6.4 \%)$ and thousand-seed mass $(6.15 \%)$; this also shows the presence of substantial variability for these traits. Genetic parameters of the study revealed that days to heading, plant height, spike length, number of grains per spike and thousand-seed mass had moderate to high heritability and genetic advance as percent of the mean. Therefore, direct selection could be practiced to improve bread wheat for these traits. Moreover, selection of early-cycle lines which can escape the negative effects of climate change will be possible. Grain yield had strong and significant positive correlation with thousand-seed mass $\left(\mathrm{r}_{\mathrm{g}}=0.395^{\star *}\right)$, biological yield $\left(\mathrm{r}_{\mathrm{gv}}=\right.$ $\left.0.617^{\star *}\right)$ and harvest index $\left(\mathrm{r}_{\mathrm{g}}=0.731^{\star *}\right)$; selection based ${ }_{\mathrm{gv}}$ these traits will be most effective in future bread wheat yield improvement programs as they also exerted strong positive direct effects on grain yield.
\end{abstract}

Key words: bread wheat; coefficient of variation; correlation; genetic advance; path coefficients
Fenotipska variabilnost in medsebojna povezanost lastnosti genotipov krušne pšenice (Triticum aestivum L.) v severni Etiopiji

Izvleček: Informacije o fenotipski variabilnosti pomagajo pri vzgoji boljših sort. V poskusu $\mathrm{z}$ dvema ponovitvama je bilo ovrednotenih 49 genotipov krušne pšenice na območjih Jamma in Geregera z namenom določitve obsega spremenljivosti in medsebojne povezanosti enajstih lastnosti. Analiza variance je pokazala značilne razlike med genotipi $(p<0,01)$ za vse lastnosti, kar kaže, da je prisotna primerna variabilnost. Največje vrednosti genotipskega koeficienta variabilnosti so bile ugotovljene za dolžino klasa $(8,66 \%)$, število cvetočih poganjkov na rastlino $(8,4 \%)$, število zrn na klas $(6,4 \%)$ in maso1000 semen $(6,15 \%)$, kar nakazuje tudi prisotnost precejšnje spremenljivosti teh lastnostih. Raziskava genetskih parametrov je odkrila, da imajo parametri kot so dnevi do klasenja, višina rastlin, dolžina klasa, število zrn na klas in masa 1000 semen zmerno do veliko dednost in genetsko prednost v odstotku poprečja. Zaradi tega bi lahko bila izvedena neposredna selekcija za izboljšanje krušne pšenice na osnovi teh lastnosti. Še več, možen bi bil izbor zgodnejših linij, ki bi pobegnile učinkom podnebnih sprememb. Pridelek zrnja je imel močno in značilno pozitivno korelacijo $\mathrm{z}$ maso 1000 semen $\left(r_{g}=0,395^{\star *}\right)$, biološkim pridelkom $\left(r_{g}=0,617^{\star *}\right)$ in žetvenim indeksom $\left(r_{g}=0,731^{\star *}\right)$. Izbor na osnovi teh lastnosti bo najučinkovitejši $\mathrm{v}$ bodočih žlahtniteljski programih za izboljšanje pridelka krušne pšenice, ker ima neposredni pozitivni učinek na pridelek zrnja.

Ključne besede: krušna pšenica; koeficient variabilnosti; korelacija; genetska prednost; koeficienti povezanih lastnosti

1 Mettu University, Department of Plant Sciences, Bedele Campus, Bedele, Ethiopia

2 Fogera National Rice Research and Training Center, Bahir Dar, Ethiopia

3 Corresponding author, e-mail: fisseha.kirkos@gmail.com

4 Jimma University, College of Agriculture and Veterinary Medicine, Jimma, Ethiopia 


\section{INTRODUCTION}

The two wheat types, both bread (Triticum aestivum L.) and durum (T. durum Desf.), are among very important cereal crops in the world in terms of production and area coverage. In 2014, about 723.4 million tons of wheat was produced on 222.3 million hectares (ha) of land, with average yield of $3.25 \mathrm{t} \mathrm{ha}^{-1}$ worldwide (FAO, 2015). Very successful wheat producing countries in the world, like Germany and France, attained average wheat yields of 7.4 and $7.2 \mathrm{t} \mathrm{ha}^{-1}$, respectively (Yao et al., 2012). However, in Ethiopia, the national wheat cultivated area was about 1.66 million ha in 2014, and the share in production was 4.23 million metric ton, with average yield of $2.54 \mathrm{t} \mathrm{ha}^{-1}$. It was ranked third in total production among cereals behind maize and tef [Eragrostis tef (Zucc.) Trotter], and forth in area coverage after tef [E. tef (Zucc.) Trotter], maize and sorghum (CSA, 2015).

Bread wheat productivity in Ethiopia is much lower as compared to other countries. Among other things, lack of high yielding varieties is the most important bottle neck. As varieties under production may become susceptible to diseases and insects, and eventually become obsolete, continuous screening and selection of bread wheat genotypes is vital for breeders to develop new varieties. For such a purpose, a sufficiently high variability within the pools of germplasm is needed.

Variation in plant genetic resources for traits of agronomic importance provides the basis and the raw material that plays a fundamental role in crop improvement programs (Dwivedi et al., 2015). Assessment of the amount of this variation is useful to allow more effective genetic improvement (Haussmann et al., 2004). The effectiveness of selection, however, depends on the relative importance of genetic and non-genetic factors in the expression of phenotypic differences among genotypes, which is known as heritability (Fehr, 1987). Unless it is used together with genetic advance, heritability value by itself provides no indication of the amount of genetic progress (Johnson et al., 1955). Quantitative traits, like yield, are more difficult to select in a breeding program because they are influenced to a greater degree by the environment (Acquaah, 2007). For such traits, indirect selection through correlated traits becomes effective.

In bread wheat, some reports are available on phenotypic variability and traits interrelationship studies (Moghaddam et al., 1997; Ali et al., 2008; Tesfaye et al., 2014). However, the information generated so far is insufficient. The objectives of the present study, therefore, are to assess the nature and extent of phenotypic variability, to study interrelationship of traits as well as direct and indirect effects of yield attributing traits on bread wheat grain yield.

\section{MATERIALS AND METHODS}

\subsection{DESCRIPTION OF THE STUDY AREA}

The field experiment was conducted at Jamma and Geregera, experimental sites of Sirinka Agricultural Research Center, in 2015. Jamma lies between the geographical coordinates of $10^{\circ} 38^{\prime} \mathrm{N}$ latitude and $39^{\circ} 20^{\prime} \mathrm{E}$ longitude, at an altitude of 2600 m. a. s. 1.; the soil type is vertisol with $\mathrm{pH}$ of 6.0 , and has total rainfall of 720.5 $\mathrm{mm}$. Geregera is located at an altitude of $2650 \mathrm{~m}$. a. s. 1, which lies between $11^{\circ} 46^{\prime} \mathrm{N}$ latitude and $38^{\circ} 45^{\prime} \mathrm{E}$ longitude; it has annual rainfall of $1105 \mathrm{~mm}$, the soil type is lithosol with $\mathrm{pH}$ of 5.6.

\subsection{PLANTING MATERIALS}

Forty-nine bread wheat genotypes, 22 released varieties and 27 elite materials were used in the study. The genotypes are believed to be adapted to the tropical condition of Ethiopia, hence spring wheat types. Variety 'Alidoro' was sourced from Holeta Agricultural Research Center; 'Gassay' and 'TAY' from Adet; 'MadaWolabu', 'Sofumar', 'UTQUE96/3/PYN/BAU//MILLAN' and 'WORRAKATTA/PASTOR' from Sinana; 'Mekelle-3' and 'Mekelle-4' from Mekelle; and the rest were sourced from Kulumsa Agricultural Research Center (Table 1).

\subsection{EXPERIMENTAL DESIGN AND TRIAL MAN- AGEMENT}

The experiment was laid out in $7 \times 7$ simple lattice design with two replications. The dimension of an indi-

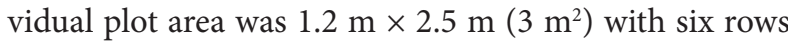
for each entry. The spacing between blocks, plots and rows were $1.5 \mathrm{~m}, 0.4 \mathrm{~m}$ and $0.2 \mathrm{~m}$, respectively. Planting was done with the seed rate of $150 \mathrm{~kg} \mathrm{ha}^{-1}$ (45 g plot $\left.{ }^{1}\right)$. Diammonium phosphate (DAP) and urea fertilizers were applied at the rate of $100 \mathrm{~kg} \mathrm{ha}^{-1}$. The total dose of DAP was applied at planting, while urea was splitted $1 / 3$ at planting and $2 / 3$ at mid-tillering stages. All the other recommended agronomic practices were applied uniformly to all plots.

\subsection{DATA COLLECTION}

Data on phenological, agronomic, yield and yield 
components were recorded. For plant height $(\mathrm{cm})$, number of productive tillers per plant, spike length $(\mathrm{cm})$ number of spikelets per spike and number of grains per spike, data were collected from ten randomly selected plants from the central four rows and the mean values were computed. The data for days to heading (number of days from sowing till flowering) and maturity (number of days from sowing till maturity), thousand-seed mass $(\mathrm{g})$, biological yield $\left(\mathrm{kg} \mathrm{m}^{-2}\right)$, grain yield $\left(\mathrm{qt} \mathrm{ha}^{-1}\right)$ and harvest index (\%) were collected on plot basis from the central four rows $\left(2 \mathrm{~m}^{2}\right)$.

\subsection{STATISTICAL ANALYSES}

The data collected were subjected to the analysis of variance (ANOVA) for simple lattice design using SAS version 9.2 (SAS Institute, 2008). Test of homogeneity of error variance of each character for the two locations was done by using F-max ratio (Hartley, 1950) before combining the data. Following the analysis of variance, phenotypic and genotypic coefficients of variation (PCV and GCV) were estimated from the corresponding genotypic and phenotypic components of variances as suggested by Burton and DeVane (1953). Heritability $\left(h^{2}\right)$ in the broad sense and genetic advance (GA) were calculated with the method suggested by Johnson et al. (1955). Genetic advance as percent of the mean (GAM) was calculated by dividing the expected genetic advance by the respective mean of the traits studied and multiplying by hundred.

Phenotypic and genotypic correlation coefficients were computed using GENRES statistical software (Pascal Intl Software Solutions, 1994) using the procedure suggested by Miller et al. (1958) from the corresponding variance and covariance components. The

Table 1: Description of the 49 bread wheat genotypes used in the study

\begin{tabular}{|c|c|c|c|c|c|}
\hline S.N. & Genotype & Status & S.N. & Genotype & Status \\
\hline 1 & 'Alidoro' & Released & 26 & 'ETBW 8514' & Elite line \\
\hline 2 & 'Biqa' & Released & 27 & 'ETBW 8515’ & Elite line \\
\hline 3 & 'Danda'a' & Released & 28 & 'ETBW 8516’ & Elite line \\
\hline 4 & 'Digelu' & Released & 29 & 'ETBW 8517’ & Elite line \\
\hline 5 & 'ETBW 6861' & Elite line & 30 & 'ETBW 8518' & Elite line \\
\hline 6 & 'ETBW 6940’ & Elite line & 31 & 'ETBW 8519’ & Elite line \\
\hline 7 & 'ETBW 7038’ & Elite line & 32 & 'Gassay' & Released \\
\hline 8 & 'ETBW 7058’ & Elite line & 33 & 'Hidasse' & Released \\
\hline 9 & 'ETBW 7101’ & Elite line & 34 & 'Hoggana' & Released \\
\hline 10 & 'ETBW 7120’ & Elite line & 35 & 'Honqolo' & Released \\
\hline 11 & 'ETBW 7147’ & Elite line & 36 & 'Hulluka' & Released \\
\hline 12 & 'ETBW 7194’ & Elite line & 37 & 'Jeferson' & Released \\
\hline 13 & 'ETBW 7213’ & Elite line & 38 & 'Kakaba' & Released \\
\hline 14 & 'ETBW 7364’ & Elite line & 39 & 'King Bird' & Registered \\
\hline 15 & 'ETBW 7368’ & Elite line & 40 & 'Mada-Wolabu' & Released \\
\hline 16 & 'ETBW 7871' & Elite line & 41 & 'Mekelle-3' & Released \\
\hline 17 & 'ETBW 7872’ & Elite line & 42 & 'Mekelle-4' & Released \\
\hline 18 & 'ETBW 8506’ & Elite line & 43 & 'Ogolcho' & Released \\
\hline 19 & 'ETBW 8507’ & Elite line & 44 & 'Pavon-76' & Released \\
\hline 20 & ‘ETBW 8508’ & Elite line & 45 & 'Shorima' & Released \\
\hline 21 & 'ETBW 8509’ & Elite line & 46 & 'Sofumar' & Released \\
\hline 22 & 'ETBW 8510’ & Elite line & 47 & 'TAY' & Released \\
\hline 23 & 'ETBW 8511’ & Elite line & 48 & 'UTQUE96/3/PYN/BAU//MILLAN’ & Released \\
\hline 24 & 'ETBW 8512’ & Elite line & 49 & 'WORRAKATTA/PASTOR' & Released \\
\hline 25 & 'ETBW 8513' & Elite line & & & \\
\hline
\end{tabular}


significance of genotypic correlation coefficients were tested using the formula adopted by Robertson (1959). Path coefficient analysis was done following the method suggested by Dewey and Lu (1959).

\section{RESULTS AND DISCUSSION}

\subsection{ANALYSIS OF VARIANCE}

As the relative efficiency of the simple lattice design was less than that of the randomized complete block design (RCBD) for most characters, and blocks within replication sum of squares were non-significant, the analysis of variance (ANOVA), therefore, was performed using RCBD model. The combined ANOVA for the two locations was run as the assumption for homogeneity of error variances was met.

The result of the combined analysis for different studied traits is shown in Table 2. Mean squares of genotypes for all characters studied were significant $(p$ $<0.05$ ), indicating the existence of genetic variability within genotypes to be exploited in breeding programs. The coefficient of determination $\left(\mathrm{R}^{2}\right)$ ranged from 0.77 for number of grains per spike to 0.95 to grain yield indicating that from $77 \%$ to $95 \%$ of the variation in the genotypes was explained by the traits considered. The location effect was significant $(p<0.01)$ for all traits, indicating the different climatic conditions in the two locations. Furthermore, location $\times$ genotype interaction effect was significant for all traits except number of spikelets per spike indicating different performance of bread wheat genotypes across the two locations (Table 2 ). The present investigation is in conformity with early findings (Tesfaye et al., 2014; Ferede and Worede, 2016; Mesele et al., 2016).

\subsection{GENOTYPIC AND PHENOTYPIC COEFFI- CIENTS OF VARIATION}

The genotypic coefficient of variation (GCV) ranged from $1.88 \%$ for days to maturity to $8.66 \%$ for spike length; and phenotypic coefficient of variation (PCV) ranged from $2.3 \%$ for days to maturity to $13.3 \%$ for number of productive tillers (Table 3). Maximum value of GCV was recorded for spike length $(8.66$ $\%)$, followed by number of productive tillers ( $8.4 \%)$, number of grains per spike $(6.4 \%)$ and thousand-seed mass $(6.15 \%)$; whereas the highest value of PCV was recorded for productive tillers $(13.3 \%)$ followed by grain yield (11.35\%), spike length $(10.3 \%)$ and harvest index $(9 \%)$.

The magnitude of PCV was much higher than the corresponding GCV for number of productive tillers, grain yield, harvest index and biological yield indicating that the apparent variation for the characters was not only genotypic but also environmental. This result agrees with the findings of Mohammedi et al. (2011).

\subsection{HERITABILITY IN THE BROAD SENSE}

Heritability estimate for characters under study is

Table 2: Estimated values of mean squares, coefficient of variation (CV) and $\mathrm{R}^{2}(\%)$ for 11 traits of 49 bread wheat genotypes combined over two locations

\begin{tabular}{|c|c|c|c|c|c|c|c|}
\hline Traits & $\mathrm{L}(\mathrm{df}=1)$ & $\mathrm{G}(\mathrm{df}=48)$ & $\mathrm{G} \times \mathrm{L}(\mathrm{df}=48)$ & Error $(\mathrm{df}=96)$ & CV (\%) & LSD (5\%) & $\mathrm{R}^{2}(\%)$ \\
\hline $\mathrm{DH}$ & $65.15^{\star *}$ & $58.12^{\star *}$ & $10.5^{\star \star}$ & 3.11 & 2.65 & 2.48 & 0.92 \\
\hline $\mathrm{DM}$ & $650.3^{* *}$ & $34.67^{\star *}$ & $11.70^{*}$ & 5.9 & 1.9 & 3.41 & 0.84 \\
\hline $\mathrm{PH}(\mathrm{cm})$ & $4662^{\star *}$ & $117.4^{* *}$ & $44.7^{\star \star}$ & 25.5 & 6.45 & 7.09 & 0.84 \\
\hline NPTP & $9.48^{\star *}$ & $0.163^{\star *}$ & $0.10^{\star *}$ & 0.06 & 16.3 & 0.35 & 0.81 \\
\hline $\mathrm{SL}(\mathrm{cm})$ & $99.26^{\star *}$ & $2.40^{* *}$ & $0.710^{\star}$ & 0.46 & 8.97 & 0.94 & 0.86 \\
\hline NSPS & $321.4^{* *}$ & $3.50^{* *}$ & $1.30 \mathrm{~ns}$ & 1.13 & 7.3 & 1.48 & 0.84 \\
\hline NGS & $922.4^{\star *}$ & $40.5^{\star *}$ & $17.00^{*}$ & 11.27 & 8.9 & 4.71 & 0.77 \\
\hline TSM (g) & $9839^{* *}$ & $41.30^{* *}$ & $16.15^{\star}$ & 6.8 & 7.11 & 3.9 & 0.94 \\
\hline $\mathrm{BY}\left(\mathrm{kg} \mathrm{m}^{-2}\right)$ & $23.40^{* *}$ & $0.140^{* *}$ & $0.088^{* *}$ & 0.045 & 10 & 0.299 & 0.89 \\
\hline HI (\%) & $1.070^{* *}$ & $0.00311^{\star *}$ & $0.0021^{\star}$ & 0.0014 & 9.66 & 0.043 & 0.94 \\
\hline GY (qt ha-1) & $35311.8^{\star *}$ & $61.72^{\star *}$ & $43.75^{\star \star}$ & 22.5 & 13.7 & 6.66 & 0.95 \\
\hline
\end{tabular}

$\mathrm{L}=$ Location, $\mathrm{G}=$ genotype, $\mathrm{G} \times \mathrm{L}=$ Genotype-location interaction, $\mathrm{df}=$ degrees of freedom, $\mathrm{DH}=$ Days to heading, $\mathrm{DM}=\mathrm{Days}$ to maturity, $\mathrm{PH}=$ plant height, NPTP $=$ number of productive tillers per plant, $\mathrm{SL}=$ Spike length, NSPS $=$ Number of spikelets per spike, NGS $=$ Number of grains per spike, $\mathrm{BY}=$ Biological yield, $\mathrm{HI}=$ Harvest index, $\mathrm{TSM}=$ Thousand-seed mass and GY = Grain yield 
presented in Table 3. In the study, heritability in broad sense ranged from $29 \%$ for grain yield to $82 \%$ for days to heading. Heritability is categorized as low $(0-30 \%)$, moderate (30-60 \%) and high (60\% and above) as given by Comstock and Robinson (1952).

Accordingly, high heritability was estimated for days to heading ( $82 \%)$, days to maturity (66.2\%), spike length (70.4\%), plant height (63.6), number of spikelets per spike (62.5) and thousand-seed mass (61\%). Similar results were documented by Laghari et al. (2010). Moreover, Ali et al. (2008) reported high estimates of heritability for spike length and number of spikelets per spike in bred wheat. However, in contrast to the results of this study, Tesfaye et al. (2014) reported low estimates of heritability for those traits. The reasons for the disagreement in the findings may be due to differences in the type and number of genetic materials used, and differences in environmental conditions.

Moderate heritability was obtained for number of grains per spike, number of productive tillers, harvest index and biological yield, indicating that the characters were influenced by environment to some extent. Low heritability was obtained for yield per ha (29\%). Low heritability estimates for yield, ranging from $7.4 \%$ to $25 \%$, were documented for grain yield (Mohammadi et al., 2011; Tesfaye et al., 2014; Mesele et al., 2016).

\subsection{EXPECTED GENETIC ADVANCE}

Genetic advance as percent of the mean (GAM) ranged from $3.15 \%$ for days to maturity to $14.9 \%$ for spike length (Table 3). Relatively high GAM values were recorded for spike length $(14.9 \%)$ followed by number of productive tillers per plant (10.6\%), number of grains per spike (10\%), thousand-seed mass (10\%), days to heading $(9.7 \%)$ and plant height $(9.07 \%)$, indicating good response to selection. The present study was in close agreement with the findings of Mohammadi et al. (2011), Mesele et al. (2016) and Rahman et al. (2016). The genetic advance for grain yield was 2.36 $\mathrm{qt} \mathrm{ha}^{-1}$. This indicates by selecting $5 \%$ of the high yielding genotypes from the base population, mean yield of the new population would increase from 34.6 to 36.96 qt ha ${ }^{-1}$.

High heritability accompanied with relatively high genetic advance in case of days to heading, plant height, spike length and thousands-seed mass indicates that the heritability is the most likely due to additive gene effects. In such cases early generation selection for these traits may be effective. In the present study, high heritability estimates along with low genetic advance, however, indicates that non additive type of gene action and environment play significant role in the expression of the traits as observed in days to maturity. The result agrees with the findings of Majumder et al. (2008).

In general, traits like spike length and thousandseed mass showed high heritability along with high GAM, PCV and GCV; while number of grains per spike had moderate heritability along with high GAM, PCV and GCV in this study. Thus, direct selection could be practiced to improve bread wheat for these traits.

Table 3: Estimates of range, means, genotypic $\left(\sigma^{2} \mathrm{~g}\right)$ and phenotypic $\left(\sigma^{2} \mathrm{p}\right)$ variances, heritability $\left(\mathrm{h}^{2}\right)$ and genetic advance (GA) for 11 traits of 49 bread wheat genotypes, combined across the locations

\begin{tabular}{llllllllll}
\hline Traits & Range & Mean $\pm \mathrm{SE}$ & $\delta_{\mathrm{g}}^{2}$ & $\delta_{\mathrm{p}}^{2}$ & $\mathrm{GCV}(\%)$ & $\mathrm{PCV}(\%)$ & $\mathrm{h}^{2}(\%)$ & $\mathrm{GA}$ & $\mathrm{GAM}$ \\
\hline DH & $61-79.5$ & $66.6 \pm 0.04$ & 11.90 & 14.53 & 5.20 & 5.72 & 82.0 & 6.45 & 9.70 \\
DM & $124-136$ & $127.6 \pm 0.22$ & 5.74 & 8.67 & 1.88 & 2.30 & 66.2 & 4.02 & 3.15 \\
PH & $68-93.75$ & $78.3 \pm 0.084$ & 18.7 & 29.35 & 5.50 & 6.90 & 63.6 & 7.10 & 9.07 \\
NPTP & $1.2-1.95$ & $1.5 \pm 0.214$ & 0.016 & 0.040 & 8.40 & 13.3 & 38.7 & 0.16 & 10.6 \\
SL & $6.4-10.9$ & $7.5 \pm 0.104$ & 0.422 & 0.600 & 8.66 & 10.3 & 70.4 & 1.12 & 14.9 \\
NSPS & $13-17.4$ & $14.6 \pm 0.78$ & 0.550 & 0.880 & 5.10 & 6.44 & 63.0 & 1.21 & 8.30 \\
NGS & $29-45.7$ & $37.8 \pm 0.11$ & 5.850 & 10.12 & 6.40 & 8.42 & 57.8 & 3.80 & 10.0 \\
TSM & $34.8-48$ & $40.8 \pm 0.10$ & 6.29 & 10.32 & 6.15 & 7.86 & 61.0 & 4.04 & 10.0 \\
BY & $1.8-2.70$ & $2.12 \pm 0.123$ & 0.013 & 0.035 & 5.38 & 8.82 & 37.0 & 0.143 & 6.73 \\
HI & $0.26-0.36$ & $0.31 \pm 0.16$ & 0.00025 & 0.00078 & 5.10 & 9.00 & 32.0 & 0.018 & 5.95 \\
GY & $26.5-43.8$ & $34.6 \pm 0.20$ & 4.50 & 15.43 & 6.13 & 11.35 & 29.1 & 2.360 & 6.80 \\
\hline
\end{tabular}

GCV and PCV = Genotypic and phenotypic coefficient of variation, GAM = Genetic advance as percent of the mean, DH $=$ Days to heading, $\mathrm{DM}=$ Days to maturity, $\mathrm{PH}=$ Plant height, NPTP $=$ Number of productive tillers per plant, $\mathrm{SL}=$ Spike length, NSPS $=$ Number of spikelets per spike, NGS $=$ Number of grains per spike, TSM $=$ Thousand-seed mass, BY $=$ Biological yield, $\mathrm{HI}=$ Harvest index, GY $=$ Grain yield 


\subsection{CORRELATIONS ANALYSIS OF QUANTITA- TIVE TRAITS}

Genotypic and phenotypic correlations of all possible combinations of the traits under study are presented in Table 4. In general, the magnitude of the genotypic correlation coefficients $\left(r_{g}\right)$ was higher than the corresponding phenotypic correlation coefficients $\left(r_{p}\right)$. This reveals the superiority of genetic variance in expression of the traits and that association among characters is under genetic control.

Days to maturity was significantly associated with days to heading $\left(\mathrm{r}_{\mathrm{g}}=0.946^{* *}\right)$ and biological yield per plot $\left(r_{g}=-0.306^{*}\right)$ at genotypic level. The negative association with biological yield connote that late maturing genotypes tend to have low biological yield. The correlation between plant height and grain yield per ha was positive and significant at both genotypic and phenotypic levels $\left(r_{g}=0.384^{* *}, r_{p}=0.354^{*}\right)$ which indicates an increase in plant height also leads to an increase in grain yield. Similar results in association with bread wheat have been reported by Moghaddam et al. (1997) and Gelalcha and Hanchinal (2013).

Thousand-seed mass had positive and significant association with grain yield per ha at genotypic and phenotypic levels $\left(r_{g}=0.395^{*}, r_{p}=0.365\right)$. This result is in agreement with the works of Laei et al. (2012) and Zafarnaderi et al. (2013). There were also significant genotypic correlations with plant height $\left(0.377^{\star *}\right)$ and harvest index $\left(0.396^{* *}\right)$. Biological yield was in positive and significant relationship with grain yield at both phenotypic and genotypic levels $\left(r_{g}=0.617^{\star *}, r_{p}=\right.$ $\left.0.624^{* *}\right)$. These results are supported by the findings of Chowdhry et al. (1991) and Laei et al. (2012).

Harvest index had positive and significant relationship at both genotypic and phenotypic levels with grain yield per ha $\left(r_{g}=0.731^{\star *}, r_{p}=0.625^{\star}\right)$. These results are supported by the findings of Chowdhry et al. (1991), Laei et al. (2012) and Zafarnaderi et al. (2013). It was negatively correlated with days to heading, days to maturity, spike length and thousand-seed mass at genotypic level. The result agreed with the findings of Moghaddam et al. (1997), but contradicted with the findings of Zafarnaderi et al. (2013).

The study of correlation among yield and yield attributing traits showed that plant height, number of productive tillers per plant, thousand-seed mass, harvest index and biological yield had positive and significant association with grain yield at genotypic level. Therefore, these traits could be utilized for indirect selection in breeding programs to improve bread wheat for yield. However, it is probably better to investigate

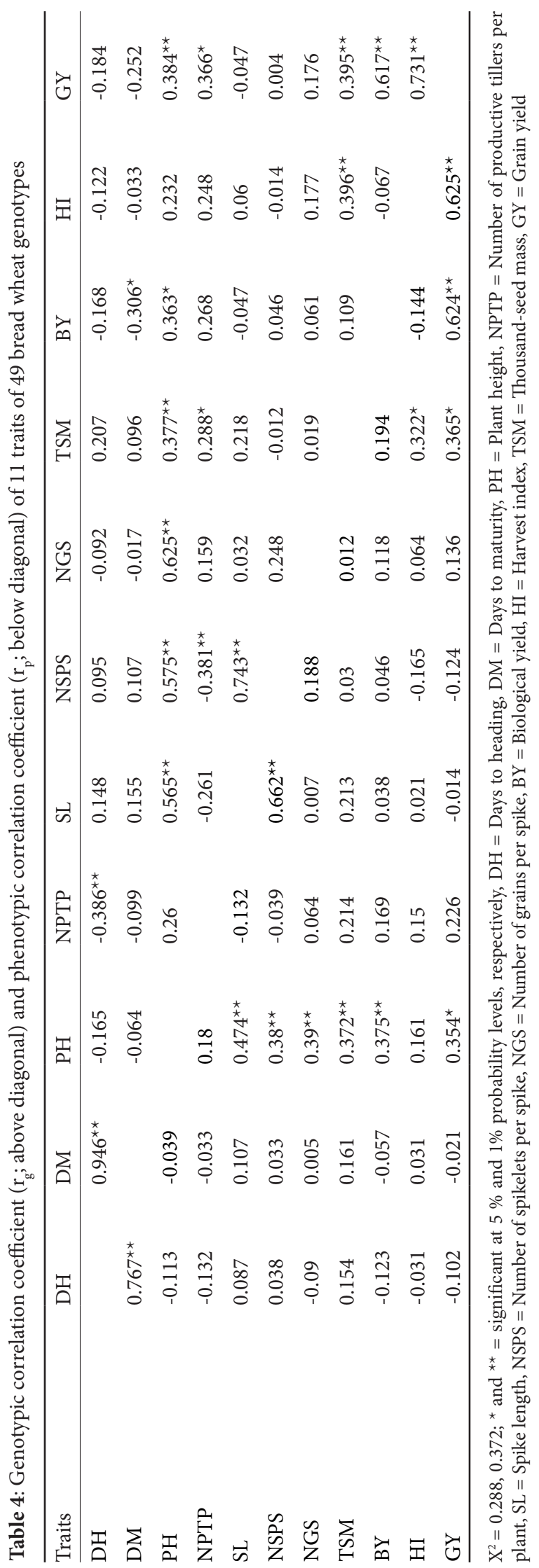


the direct and indirect effects of these traits on grain yield.

\subsection{PATH COEFFICIENT ANALYSIS}

As the number of interdependent characters affecting a dependent character increases, correlation alone becomes insufficient to explain relationships among characters (Ariyo et al., 1987). In such cases, path coefficient analysis, identification of direct and indirect causes of association becomes indispensable.

Estimates of path coefficients were presented in Table 5. Maximum positive direct effect on grain yield per ha was exerted by harvest index $(0.753)$, followed by biomass yield (0.753). The high direct effects of these traits on grain yield could be considered as causes of the strong correlation; an increase in harvest index and biological yield directly contribute to an increase in grain yield. Chowdhry et al. (1991) also reported positive direct effects of harvest index (0.443) and biological yield (0.327) on grain yield per plant. Thousand-seed mass was the other trait with positive direct effect (0.161) on yield; it also had substantial effect on grain yield indirectly through harvest index $\left(0.298^{\star}\right)$. On the other hand, negative direct effects were exerted on grain yield by plant height $(-0.215)$ and number of productive tillers per plant (-0.078). However, the consequent counter balancing of the positive and substantial indirect effects of thousand-seed mass, harvest index and biological yield led to positive and significant correlation of these traits with grain yield. This justifies the importance of splitting genotypic correlation coefficients into direct and indirect effects by using path coefficient analysis.

On the basis of estimates of path coefficients, it could be suggested that harvest index followed by biological yield and thousand-seed mass are the direct contributors to grain yield in the present investigation. The result agrees with Gashaw et al. (2007) and Gela- lcha and Hanchinal (2013). Biological yield, harvest index and thousand-seed mass, which had highly significant correlation with grain yield and positive direct effects, could be used as selection index in grain yield improvement of bread wheat.

To this end, the residual effect in the present study (0.126) shows that $87.4 \%$ of the variability in grain yield was explained by the component traits, while $12.6 \%$ is due to the interventions of unexplained factors (error and traits not included). The result is in conformity with the findings of Gashaw et al. (2007) and Gelalcha and Hanchinal (2013), who reported residual effects of 0.065 and 0.0083 , respectively.

\section{CONCLUSIONS}

Overall variability within a crop is due to heritable and non-heritable components. In the present investigation, maximum GCV values of spike length (8.66 \%) followed by number of productive tillers $(8.4 \%)$, number of grains per spike $(6.4 \%)$ and thousand-seed mass $(6.15 \%)$ shows the presence of sizable variability for these traits. Improvement of bread wheat could be based on direct selection for days to heading, plant height, spike length, number of grains per spike and thousandseed mass as these traits had moderate to high values of heritability and genetic advance as percent of the mean. Significant positive correlation along with strong positive direct effects on grain yield were achieved by thousand-seed mass, harvest index and biological yield; consequently, these traits could be used as indirect selection criteria to improve bread wheat grain yield.

\section{ACKNOWLEDGEMENTS}

The first author would like to thank Sirinka Agricultural Research Center (SARC) for providing experimental fields. Thanks also due to Mr. Zerihun Tadesse

Table 5: Estimate of direct (bold face and diagonal) and indirect (off diagonal) effects at genotypic level in five traits of 49 bread wheat genotypes

\begin{tabular}{lllllll}
\hline Traits & PH & NPTP & TSM & BY & HI & $r_{g}$ \\
\hline PH & -0.215 & -0.020 & 0.061 & 0.273 & 0.174 & $0.384^{\star *}$ \\
NPTP & -0.056 & -0.078 & 0.046 & 0.202 & 0.187 & $0.366^{\star}$ \\
TSM & -0.081 & -0.023 & 0.161 & 0.082 & $0.298^{\star}$ & $0.395^{\star *}$ \\
BY & -0.078 & -0.021 & 0.018 & $0.753^{\star *}$ & -0.050 & $0.617^{\star \star}$ \\
HI & -0.050 & -0.019 & 0.064 & -0.050 & $0.753^{* *}$ & $0.731^{\star *}$ \\
\hline
\end{tabular}

Residual effect $=0.126{ }^{*}$ and ${ }^{* *}$ significant at 0.05 and 0.01 probability levels, $\mathrm{PH}=$ Plant height, NPTP $=$ Number of productive tillers per plant, $\mathrm{TSM}=$ Thousand-seed mass, $\mathrm{BY}=$ Biological yield, $\mathrm{HI}=$ Harvest index, $\mathrm{r}_{\mathrm{g}}=$ Genotypic correlation 
for availing wheat seeds, to research assistants of SARC for the help on the research field.

\section{REFERENCES}

Acquaah, G. (2007). Principles of plant genetics and breeding. Black well Publishing, USA.

Ali, Y., Atta, B.M., Akhter, J., Monneveux, P. and Lateef, Z. (2008). Genetic variability, association and diversity studies in wheat (Triticum aesitum L.) germplasm. Pakistan Journal of Botany, 40(5), 2087-2097.

Ariyo, O.J., Aken'ova, M.E. and Fatokun, C.A. (1987). Plant character correlation and path analysis of pod yield in Okra (Abelmoschus esculentus). Euphytica, 36, 677-686. https://doi.org/10.1007/BF00041518

Burton, G.W. and DeVane, E.H. (1953). Estimating heritability in tall fescue (Festuca arundinacea) from replicated clonal material. Agronomy Journal, 45, 487-488. https://doi. org/10.2134/agronj1953.00021962004500100005x

Chowdhry, M.S., Alam, K. and Khaliq, I. (1991). Harvest index in bread wheat. Pakistan Journal of Agricultural Sciences, 28(2), 207- 210.

Comstock, R. R. and Robinson, H. F. (1952). Genetic parameters, their estimation and significance. Proceedings of the $6^{\text {th }}$ International Grassland Congress (pp. 248-291). Washington, DC.

Central Statistical Agency (CSA). (2015). Agricultural sample survey for 2014/2015: Area and production of major crops. Volume I. Addis Ababa, Ethiopia.

Dewey, D.R. and Lu, K.H. (1959). A correlation and path coefficient analysis of components of crested wheat grass seed production. Agronomy Journal, 51, 515-558. https://doi. org/10.2134/agronj1959.00021962005100090002x

Dwivedi, S.L., Sahrawat, K.L., Upadhyaya, H.D., Mengoni, A., Galardini, M., Bazzicalupo, M., Biondi, E.G., Hungria, M., Kaschuk, G., Blair, M.W., Ortiz, R. (2015). Advances in host plant and rhizobium genomics to enhance symbiotic nitrogen fixation in grain legumes. Advances in Agronomy, 129, 1-116. https://doi.org/10.1016/bs.agron.2014.09.001

Fehr, W.R. (1987). Principles of cultivar development: Theory and technique. Volume I. McGraw-Hill. New York.

Ferede, M. and Worede, F. (2016). Grain yield stability and phenotypic correlation analysis of bread wheat (Triticum aestivum L.) genotypes in north western Ethiopia. Food Science and Quality Management, 48, 51-59.

Gashaw, A., Mohammed, H. and Singh, H. (2007). Selection criterion for improved grain yields in Ethiopian durum wheat genotypes. African Crop Science Journal, 15(1), 25 31.https://doi.org/10.4314/acsj.v15i1.54407

Gelalcha, S., and Hanchinal, R. R. (2013). Correlation and path analysis in yield and yield components in spring bread wheat (Triticum aestivum L.) genotypes under irrigated condition in Southern India. African Journal of Agricultural Research, 8(24), 3186-3192. https://doi.org/10.5897/ AJAR2013.6965

Hartley, H.O. (1950). The maximum F-ratio as a short cut test for heterogeneity of variances. Biometrika, 37, 308-312. https://doi.org/10.2307/2332383

Haussmann, B.I.G., Parzies, H.K., Presterl, T., Susic, Z., and Miedaner, T. (2004). Plant genetic resources in crop improvement. Plant Genetic Resources, 2(1): 3-21. https://doi. org/10.1079/PGR200430

Johnson H.W., Robinson, H.F. and Comstock, R.E. (1955). Estimates of genetic and environmental variability in soyabeans. Agronomy Journal, 47, 314-318. https://doi. org/10.2134/agronj1955.00021962004700070009x

Laei, G., Afshari, H., Kamali, M. R. J. and Hassanzadeh, A. (2012). Study yield and yield components comparison correlation some physiological characteristics, 20 genotypes of bread wheat. Annals of Biological Research, 3(9), 4343-4351.

Laghari, K. A., Sial, M. A., Arain, M. A., Dahot, M. U., Mangrio, M. S. and Pirzada, A. J. (2010). Comparative performance of wheat advance lines for yield and its associated traits. World Applied Sciences, 8, 34-37.

Majumder, D.A.N., Shamsuddin, A.K.M., Kabir, M.A. and Hassan, L. (2008). Genetic variability, correlated response and path analysis of yield and yield contributing traits of spring wheat. Journal of the Bangladesh Agricultural University, 6(2), 227-234. https://doi.org/10.3329/jbau.v6i2.4815

Mesele, A., Mohammed, W. and Dessalegn, T. (2016). Estimation of heritability and genetic advance of yield and yield related traits in bread wheat (Triticum aestivum L.) genotypes at Ofla district, Northern Ethiopia. International Journal of Plant Breeding and Genetics, 10, 30-37. https:// doi.org/10.3923/ijpbg.2016.31.37

Miller, P.A., Williams, J.C., Robinson, H.F. and Comstock, R.E. (1958). Estimates of genotypic and environmental variances and covariances in upland cotton and their implications in selection. Agronomy Journal, 50, 126-131. https:// doi.org/10.2134/agronj1958.00021962005000030004x

Moghaddam, M., Ehdaie, B. and Waines, J.G. (1997). Genetic variation and interrelationships of agronomic characters in landraces of bread wheat from southeastern Iran. Euphytica, 95, 361-369. https://doi.org/10.1023/A:1003045616631

Mohammadi, M., Karimizadeh, R., Shefazadeh, M.K. and Sadeghzad, B. (2011). Statistical analysis of durum wheat yield under semi-warm dryland condition. Australian Journal of Crop Science, 5(10), 1292-1297.

Rahman, M.A., Kabir, M.L., Hasanuzzaman, M., Rahman, M.A., Rumi, R.H. and Afrose, M.T. (2016). Study of variability in bread wheat (Triticum aestivum L.). International Journal of Agronomy and Agricultural Research, 8(5), 66-76.

Robertson, G.E. (1959). The sampling variance of the genetic correlation coefficient. Biometrics, 15, 469-485. https://doi. org/10.2307/2527750

Tesfaye, T., Genet, T. and Desalegn, T. (2014). Genetic variability, heritability and genetic diversity of bread wheat (Triticum aestivum L.) genotype in western Amhara region, Ethiopia. Wudpecker Journal of Agricultural Research, 3(1), 26-034.

Yao, J., Ma, H., Yang, X., Yoa, G.U. and Zhou, M. (2014). Inheritance of grain yield and its correlation with yield components in bread wheat (Triticum aestivum L.). Af- 
rican Journal of Biotechnology, 13, 1379-1385. https://doi. org/10.5897/AJB12.2169

Zafarnaderi, N., Aharizad, S. and Mohammadi, S.A. (2013). Relationship between grain yield and related agronomic traits in bread wheat recombinant inbred lines under water deficit condition. Annals of Biological Research, 4(4), 7-11. 